\title{
Transformasi Musik Arumba: Wujud Hibriditas Yang Mengglobal
}

\author{
Hinhin Agung Daryana, Dyah Murwaningrum \\ Program Studi Angklung dan Musik Bambu, Fakultas Seni Pertunjukan, \\ Institut Seni Budaya Indonesia Bandung \\ Jalan Buah Batu No. 212 Bandung 40265 \\ Email: hinhin_agung@isbi.ac.id
}

\begin{abstract}
This study is focused on the transformation of Arumba music, which was emerged following its popularity among Bandung society. This transformation is a response to social and cultural changes among its audiences. Since its appearance, Arumba is used mostly as entertainment and tourist attractions, and then in its current development, it gets an important place as subject materials to be taught in higher education. This research employed a descriptive method and qualitative approach. By using Jorgensen theory on musical transformation, the result shows that the cultural space and personal interpretation have influenced the transformation of Arumba into an interesting musical form. It can be concluded that the Arumba music transformation is an attempt for seeking the authenticity of the music. Moreover, this situation gives a significant influence, especially in determining the position, image, and the role of Arumba music in the repertoire of popular music in West Java.
\end{abstract}

Keywords: arumba, transformation, bamboo music

\begin{abstract}
ABSTRAK
Penelitian ini difokuskan pada transformasi musik Arumba yang muncul sebagai respon atas perubahan sosial budaya dari masyarakat penikmatnya. Hal ini dipengaruhi oleh popularitasnya di kalangan masyarakat Bandung. Sejak kelahirannya, musik Arumba dijadikan hiburan dan kemudian bergeser menjadi alat pendidikan di perguruan tinggi. Penelitian ini menggunakan metode deskriptif dengan pendekatan kualitatif. Dengan menggunakan teori sketsa transformasi musik Jorgensen (2005), hasil penelitian ini menunjukkan bahwa ruang budaya dan interpretasi pribadi memengaruhi transformasi yang terjadi pada musik Arumba. Dapat disimpulkan bahwa transformasi musik Arumba adalah reaksi pelaku musik (seniman) dalam upaya mencari otentisitas musiknya. Selain itu, fenomena ini menyebabkan dampak yang cukup signifikan, terutama dalam menentukan posisi, citra, dan peran musik Arumba dalam repertoar musik populer di Jawa Barat.
\end{abstract}

Kata kunci: arumba, transformasi, musik bambu 


\section{PENDAHULUAN}

Masyarakat modern sangat sadar bahwa musik merupakan sebuah peristiwa yang mengalir. Dengan melewati batas ruang dan waktu, musik dapat mendefinisikan dirinya sendiri tanpa bantuan seni lainnya. Beberapa konsep baru lahir, dikembangkan, atau bahkan diciptakan, tetapi terkadang apa yang telah dilakukan oleh para pelakunya menimbulkan pertanyaan tentang identitas kultural masyarakat.

Selama beberapa puluh tahun, musik Arumba, yang dikategorikan sebagai musik bambu, mampu menarik perhatian berbagai kalangan, baik generasi muda maupun tua. Arumba adalah sebuah ensambel musik yang berisi gabungan beberapa instrumen musik bambu yang tersebar pada masyarakat, yang berdomisili di sekitar Jawa Barat. Seiring berkembangnya teknologi, kesenian ini mampu menempatkan dirinya di ruang-ruang yang sangat dekat dengan masyarakat. Tidak hanya sebagai hiburan, Arumba kini mulai dianggap sebagai komponen penting yang selalu menjadi deretan seni pertunjukan yang wajib disajikan atau dipelajari hampir di setiap sanggar seni, lokasi wisata budaya, lembaga pendidikan formal, BUMN di Bandung dan Jakarta, atau bahkan beberapa KBRI yang berada di luar negeri (Saleh, 2016). Melacak jejak sejarah musik bambu di Jawa Barat tidaklah mudah untuk menemukan validitasnya. Bukan hanya faktor budaya oral dari para leluhur kita sehingga agak sulit mencari data tertulis, tetapi juga disebabkan pergeseran fungsi yang terjadi pada instrumen musik bambu tersebut sehingga harus menggandeng instrumen lainnya agar dapat diterima masyarakat.

Arumba merupakan salah satu jenis musik rakyat sudah ada sejak 1960-an di daerah Jawa Barat. Perkembangannya tidak terlepas dari perjalanan seni angklung yang yang pertama kali dikembangkan oleh Daeng Sutigna sejak tahun 1938. Pada waktu itu, angklung merupakan suatu seni yang dimainkan secara massal oleh puluhan bahkan ratusan orang. Sekitar tahun 1960-an, Joes Rosadi mencoba melakukan inovasi dengan cara menggantungkan angklung-angklung itu pada tiang gantungan 2 tingkat agar dapat dimainkan secara perseorangan (Burhan, 2009).

Pada sektor lain, terinspirasi oleh konsep angklung yang digagas oleh Joes Rosadi, pada tahun 1966 Muhamad Burhan mendapat kesempatan untuk melatih satu grup angklung perseorangan di Cirebon yang berdampak pada dilakukannya beberapa perubahan, baik dalam bentuk maupun komposisi. Pengembangan terus dilakukan setelah Muhamad Burhan kembali ke Bandung di tahun 1970, dengan fasilitas dari Saung Angklung Udjo Burhan secara terus menerus menyempurnakan kekurangannya. Sebagaimana dijelaskan Burhan (2009), sejak saat itu musik Arumba mulai menemukan bentuknya dan semakin hari semakin dikenal masyarakat. Sampai saat ini, musik Arumba difungsikan sebagai hiburan, kesenian, serta pertunjukan pada saat acara-acara resmi di Jawa Barat. Perkembangan terkini Arumba difungsikan sebagai alat pendidikan yang dalam penyajiannya dapat dimainkan secara instrumental atau mengiringi nyanyian.

Dalam perjalanannya muncul beberapa persoalan, misalnya pengolahan instrumentasi Arumba. Saran dan kritik memang telah disampaikan oleh para seniman. Hal ini pulalah yang menjaga wacana musik Arumba menjadi sebuah seni yang dinamis dan terus dikembangkan. Persoalan mendasar di luar musik ialah eksotisme instrumen bambu yang awal mula diciptakan sebagai ciri kelokalan Sunda ternyata tidak sebanding dengan musik yang disajikan atau dimainkan para senimannya. Dalam beberapa pertunjukan skala lokal ataupun internasional dapat dicermati bahwa ciri kelokalan yang diwakili oleh instrumen 
bambu tidak sebanding dengan musik yang disajikan yang jauh dari kesan lokal. Maksudnya, dapat ditangkap kesan jika elemen musik barat terlalu mendominasi dalam musik Arumba, baik tangga nada maupun repertoarnya. Bukti yang paling mudah kita temui ialah repertoar yang disajikan kebanyakan berasal dari musik populer barat, terutama lagu-lagu hits.

Bertolak dari peristiwa tersebut fokus penelitian ini adalah bagaimana awal mula terjadinya transformasi budaya yang terjadi dalam musik Arumba. Penelitian ini diharapkan akan mampu membuat sebuah peta perkembangan musik Arumba termasuk sejarah singkat dan karakteristik musiknya. Lebih jauh lagi, hasil penelitian ini diharapkan mampu membuat wacana baru yang dapat mengembalikan pola pikir pelaku Arumba dan musik bambu secara umum di Bandung sehingga seniman pelaku musik bambu senantiasa berusaha untuk terus merumuskan format musik Arumba secara komprehensif.

\section{METODE}

Data untuk penelitian ini berasal dari wawancara intensif dengan 2 tokoh penggagas musik Arumba, yaitu Mochamad Udjang Burhan dan Budi Abdulrahman, ditambah beberapa musisi yang mempunyai reputasi dalam bidang musik Arumba. Penulis menetapkan kriteria untuk membatasi informan kepada musisi atau seniman yang berkomitmen dalam musik Arumba. Untuk kategori musisi musik Arumba, yang bersangkutan setidaknya memiliki empat kriteria: 1) pengalaman selama 5-10 tahun dalam memainkan musik arumba, baik di panggung atau rekaman; 2) menjadi anggota kelompok musik Arumba yang berlatih secara teratur (setidaknya empat kali sebulan); 3) menjadi anggota kelompok musik arumba yang setidaknya tampil di tempat umum secara teratur (setidaknya dua bulan sekali). Penetapan kriteria ini dilakukan untuk mendapat data yang valid. pembatasan narasumber yang memang benar-benar berkomitmen dalam kariernya dilakukan agar keterangan yang mereka sampaikan memang dapat dipertanggungjawabkan.

Penulis menghubungi informan tersebut dengan menggunakan dua metode utama, yaitu melalui aplikasi whatsapp dan secara langsung. Dalam praktiknya, penulis mencoba mewawancarai semua informan yang sebelumnya telah ditentukan berdasarkan pertimbangan kriteria tadi. Penjadwalan dilakukan setidaknya satu minggu sebelum wawancara dilaksanakan. Beberapa hal yang menjadi target informasi yang harus digali ialah keseluruhan proses kehidupan mereka dari masa kanak-kanak hingga masa kini, sehingga bersinggungan dengan musik Arumba. Para musisi tersebut juga kemudian menuntun saya menjalani hidup mereka, dan menelusuri pengalaman mereka belajar. Sepanjang wawancara, para musisi membahas sejauh mana musik Arumba berpengaruh terhadap identitas dan kondisi finansial mereka. Wawancara berlangsung antara 60 sampai dengan 90 menit. Penulis merekam dan menyalinnya sendiri. Dalam menganalisis data, penulis mengombinasikan grounded theory dan strategi biografi interpretatif (Denzin \& Lincoln, 1998).

\section{HASIL DAN PEMBAHASAN}

\section{Mengenal Tokoh Pembaharu Musik Arumba}

Dalam musik Arumba dikenal sejumlah tokoh pembaharu yang berjasa dalam pengembangan musik tersebut, salah satunya yang paling menonjol ialah Muhamad Udjang Burhan.

Musik Arumba dapat dikatakan sebagai perkembangan dari angklung yang pertama kali dikembangkan Daeng Sutigna sejak tahun 1938 dengan melakukan pengembangan pada wilayah tangga nada angklung dari pentatonis ke tangga nada diatonis kromatis. 


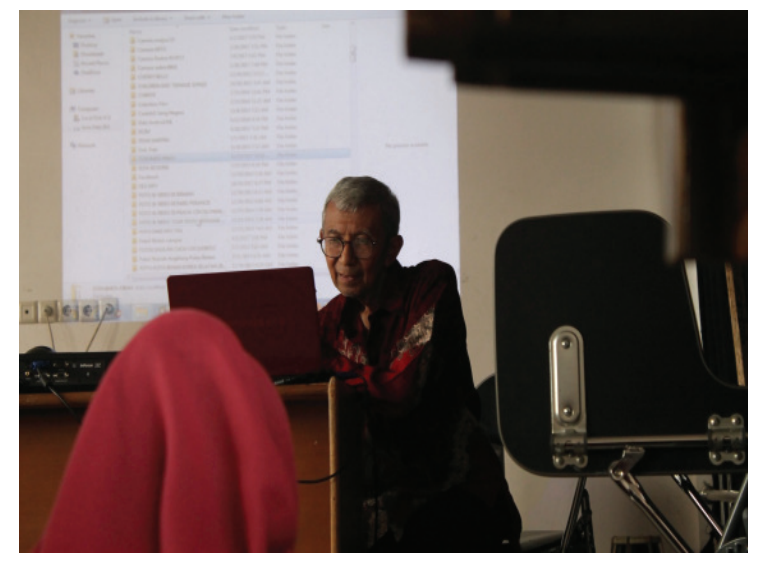

Gambar 1.

Mochamad Burhan, tokoh pembaharu musik Arumba (Dokumentasi: Daryana, 2017)

Berkembangnya angklung menjadi seni pertunjukan populer waktu itu mendorong seorang seniman angklung bernama Joes Rosadi untuk menyederhanakan permainan Angklung menjadi perseorangan. Inovasi dilakukan dengan menggantungkan angklung-angklung ini pada sebuah tiang gantungan dua tingkat. Dalam format seperti ini ensambel Angklung Daeng dapat dimainkan oleh 5-8 orang saja termasuk pemain bass.

Tanggal 25 Desember 1942, seorang anak bernama Mochamad Burhan dilahirkan di kota Bandung. Sejak kecil dia dipanggil Ujang oleh keluarga dan teman-temannya, namun saat pindah ke Jakarta dia mendapat julukan Djaka dari tokoh seniman musik Arumba bernama Tan Pi sik. Persinggungan awal Burhan dengan musik dimulai ketika beliau menginjak SMA. Pada dekade tersebut mulai banyak muncul band-band yang menarik minat anak muda. Seperti yang diungkap Sakrie (2015: 18) bahwa separuh dasawarsa 1950-an, rakyat Indonesia sudah mendengar atau membawakan lagu-lagu asing berbahasa Inggris, yang menandakan bahwa saat itu rakyat Indonesia mulai menggandrungi budaya barat yang berasal dari musik dan film.

Dari momen itu juga akhirnya Burhan mengenal musik dari Koes bersaudara dan
The Beatles. Lingkungan tempat ia tinggal dulu di daerah Pasirmalang (sekarang Pasirluyu, Kodya Bandung) memang cukup mempengaruhi karir bermusik Burhan.

Di tempat itu pula Burhan mulai banyak mendengar berita adanya pertunjukan angklung Pak Daeng yang bersifat massal. Sekali waktu ia pernah melihat pertunjukannya. Ia sangat takjub dan tertarik akan performa grup musik angklung tersebut yang saat itu membawakan lagu-lagu barat (lagu klasik), di samping lagu-lagu nasional.

Belum habis ketertarikan terhadap angklung massal, dalam sebuah acara perayaan kemerdekaan Indonesia bulan Agustus 1965 di gedung Nusantara (Bandung Mall Alun-alun Bandung) Burhan kembali melihat angklung yang dimainkan dalam format yang berbeda, yaitu dimainkan hanya oleh 5-8 orang. Kala itu Burhan muda sudah memainkan kesenian calung. Pada masa itu, kegiatan digelar dalam upaya $\mathrm{Na}$ sakomisasi, yang berarti beberapa kesenian yang waktu itu tampil seolah-olah mewakili masing-masing ideologi yang terdapat dalam NASAKOM. Pada kegiatan tersebut angklung menjadi representasi dari nasionalisme, calung mewakili agama, dan komunis diwakili oleh seni drama.

Setelah acara tersebut Burhan semakin tertarik oleh kesenian angklung perseorangan, karena ia menganggap bahwa angklung dengan format perseorangan lebih dekat dengan background dia sebagai pemain band, yang berbeda hanya media yang digunakan.

Saat itu, Burhan menyaksikan kemunculan grup musik yang menamakan dirinya grup musik ARUBA yang berasal dari Tasikmalaya di bawah arahan Joes Rosadi. Alat musik bambu yang digunakan waktu itu terdiri dari angklung melodi 1 set, angklung akompanyemen (pengiring) 1 set, koakompanyemen 1 set, bass bambu 1 set, dan vibraphone bambu 1 set. 
Semua alat yang melengkapi grup ARUBA tersebut digantungkan pada sebuah tiang gantungan (stand) dan masingmasing dimainkan oleh satu orang pemain, sehingga jumlah pemain relatif sedikit. Hal itu tidak mengurangi kepiawaian mereka dalam memainkan repertoar yang waktu itu terdiri dari lagu-lagu perjuangan dan nasional lainnya. Dalam perkembangan terakhirnya Joes Rosadi mengubah nama grup musik ARUBA menjadi Bamboo Band.

Secara kebetulan pascapertunjukan itu pula seseorang bernama Husein Amirullah tertarik untuk membeli seperangkat alat musik bambu yang digunakan oleh Joes Rosadi. Berawal dari ajakan ayahnya untuk melatih satu kelompok musik bambu tersebut, akhirnya Burhan hijrah ke Cirebon pada tahun 1966. Pada saat itu, ia mela-tih sekelompok anak-anak SMA yang menamakan grupnya Arumba Cirebon. Nama ARUMBA ini diambil sebagai akronim Alunan RUMpun BAmbu.

Pada tahun itu pula Burhan mulai melakukan beberapa eksperimen dengan beberapa perubahan-perubahan, baik dalam bentuk maupun komposisi peralatan Arumba ini. Perubahan yang dilakukan meliputi penambahan jumlah tabung angklung melodi yang asalnya dua tabung menjadi empat tabung, kemudian diletakkan atau digantungkan secara sejajar antara nada pokok dan nada sisipan.

Demikian pula dengan angklung akompanyemen dan co-akompanyemen dalam fungsinya sebagai pengiring. Burhan menggantinya dengan calung diatonis-kromatis semacam gambang bambu (Carumba), dengan maksud agar dapat lebih fleksibel dalam memainkan berbagai macam irama dan akor-akor yang digunakan.

Di tahun 1969, grup Arumba Cirebon ini mendapat kesempatan, atau lebih tepatnya tawaran untuk mengikuti Training Centre Kesenian Indonesia yang diprakarsai oleh Indonesian Artist Management (IAM) di bawah pimpinan Amir Syamsudin yang tertarik saat Arumba Cirebon melakukan latihan di rumah sekaligus restoran milik Husein Amirullah. Namun, dikarenakan satu dan lain hal rombongan ini tidak jadi diberangkatkan.

Momen itu sungguh membuat semua orang terpukul, Muhamad Burhan dan Husen mengalami kerugian waktu dan materi cukup besar. Tetapi, peristiwa itu tidak mengendorkan semangat Burhan untuk terus bermain musik Arumba, dan Burhan pun kembali ke Bandung.

\section{Perkembangan Musik Arumba di Kota Bandung Arumba di Saung Angklung Udjo}

Sekembalinya Burhan ke Bandung tahun 1970, kegiatan bermusik Arumba dilanjutkan di Saung Angklung Udjo (SAU), yang bertempat di jalan Padasuka Bandung. Semuanya berawal ketika Burhan didatangi oleh Udjo Ngalagena, pemilik Saung Angklung Udjo. Berdasarkan berita tentang Arumba yang cukup tersebar di kalangan seniman Jawa Barat waktu itu, Udjo akhirnya mendatangi Burhan untuk sekedar berbagi informasi tentang perkembangan musik Arumba.

Burhan juga ditawari utuk mengajari anak-anaknya Udjo Ngalagena. Pengembangan bisnis wisata budaya yang mulai dirintis oleh Udjo pun tidak luput dari pembicaraan mereka. Burhan akhirnya menerima tawaran itu dan mulai melatih anak-anak Udjo ditambah anggota keluarga lainnya.

Sejak saat itu, musik Arumba menjadi sebuah repertoar dalam setiap pertunjukan Bamboo Afternoon di Saung Angklung Udjo. Kemasan pertunjukan yang sebelumnya ada seperti arak-arakan, mengarak pengantin sunat tidak dihilangkan, bahkan dilengkapi dengan musik Arumba.

Lingkungan Saung Angklung Udjo membuat Burhan lebih haus untuk melakukan eksperimen, sarana dan prasarana yang 
mendukung menjadi alasan kenapa hal itu terus dilakukan. SAU menjadi laboratorium bagi Burhan dalam upaya penyempurnaan kekurangan-kekurangan yang selama ini dirasakan. Di tempat ini pula Burhan menetapkan unit musik Arumba, dengan bentuk dan komposisi peralatan sebagaimana yang makin hari makin dikenal masyarakat hari ini, antara lain: (1) Angklung melodi 3 tabung set; (2) Calung diatonis-kromatis 4 set; dan (3) Bas lodong 1 set.

Perpaduan instrumen ini merupakan perangkat pokok yang dapat ditambah dengan alat-alat perkusi lainnya seperti kendang, conga, dan alat musik penunjang lainnya, seperti cabasa, maracas, dan tok-tok. Sedangkan iringan akhirnya tidak digunakan karena fungsinya sudah terwakili oleh hadirnya calung diatonis (Carumba).

Penambahan instrumen perkusi itu diterapkan pula pada grup pertama Arumba milik Burhan, yaitu Bamboo Rhythm. Berawal dari desakan beberapa tetangga sekitar SAU di daerah Padasuka Cicaheum Bandung, Bamboo Rhythm pun akhirnya terbentuk.

Bamboo Rhythm dapat dianggap sebagai kelompok musik Arumba pertama di Bandung. Sejak tahun 70-an Burhan, dengan bantuan SAU, mulai menjalin relasi dengan beberapa perusahaan travel (wawancara, 10 Oktober 2017). Momen itu menjadi kelahiran grup Arumba lainnya, seperti Arumba The Prink, Arumba Awi Kuring, dan Arumba Parahiyangan. Hampir seluruh kelompok tersebut terkait dengan Burhan, baik sebagai anggota maupun sebagai penggagas (wawancara dengan Budi Abdulrahman, 29 Juni 2017).

Produk album dalam bentuk VCD pernah direkam dan diluncurkan ke pasaran. Walaupun lagu yang disajikan adalah lagulagu hits, baik Indonesia ataupun barat. Salah satunya adalah Arumba Parahiyangan dan Arumba Awi Kuring pada tahun 2004. Dalam konteks industri kreatif, memasukkan seni pertunjukan tradisi ke dalam me- kanisme industri dalam format VCD menjadi ciri lokalitas yang dapat berkolaborasi dengan produk teknologi modern sebagai ciri modernitas untuk menjaga dirinya tetap hidup di tengah-tengah masyarakat.

Dengan dibuatnya format VCD tidak serta merta para pelaku musik Arumba mendapatkan keuntungan dari penjualan, tetapi setidaknya upaya untuk melakukan pelestarian masih dilakukan. Perubahan lainnya terlihat ketika musik Arumba didesain sedemikian rupa untuk menjadi repertoar wajib dalam pertunjukan yang dilakukan di SAU. Dari fenomena ini dapat terlihat bahwa telah terjadi sebuah perubahan fungsi dari awalnya sebagai hiburan menjadi komoditas.

Ketika musik Arumba sudah mulai dikenal masyarakat, akhirnya pemerintah menunjukkan perhatiannya dengan menyelenggarakan sebuah festival Arumba se-Jawa Barat di tahun 1976. Acara itu digelar dalam upaya pelestarian kesenian tradisional. Pada kesempatan itu pula Burhan menjadi pelatih dari dua kontestan yang mengikuti festival tersebut, dan keduanya berhasil mendapat juara. Festival ini dibagi ke dalam 2 kategori, yaitu remaja sebanyak 12 grup dan dewasa sebanyak 10 kontestan.

Sejak awal tahun 1970 musik pop, jazz, dan rock berkembang di Indonesia setelah kebijakan anti kebudayaan barat tidak lagi diterapkan. Sebagai musik yang berakar dari barat, ketiga jenis musik itu tidak hanya tumbuh sebagai suatu ekspresi kesenian tetapi berhasil tumbuh dan berkembang menjadi suatu industri baru. Situasi ini dimanfaatkan dengan baik oleh Burhan dengan mengaransemen ulang beberapa repertoar yang hits pada zamannya diadaptasi untuk musik Arumba. Pada akhirnya, hal ini berdampak pada masuknya Arumba ke ruang-ruang publik yang lain. Dinas-dinas di pemerintahan dan kementerian menjadi ruang baru yang membawa Arumba ke tingkatan yang lebih tinggi. Undangan dari 


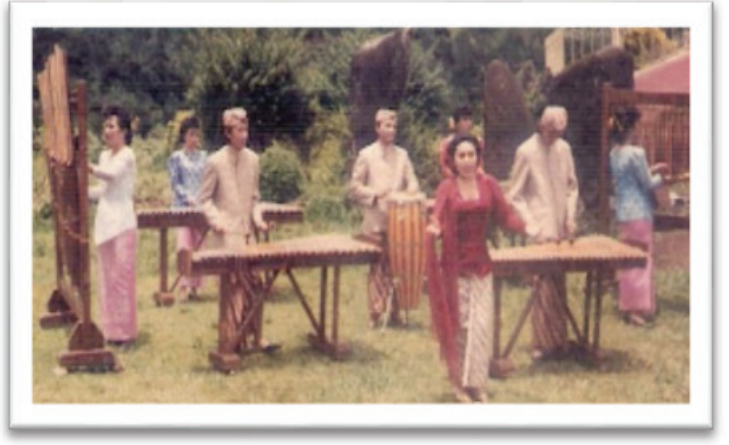

Gambar 2. Penyajian Musik arumba Di TVRI thn 1980-an bersama Hety Koes Endang

(Dokumentasi: Burhan, 2009)

luar negeri kerap kali datang, yang kemudian berlanjut pada digunakannya musik Arumba sebagai salah satu kesenian yang selalu menghiasi KBRI di beberapa negara.

Adaptasidengan pertimbangan perubahan nilai pada situasi tertentu menjadi kunci bagaimana Arumba ini dapat berkembang cukup signifikan. Di SAU akhirnya Burhan bertemu dengan seseorang dari pihak pemerintahan yang memberi tawaran untuk hijrah ke Jakarta dan bekerja sebagai pegawai negeri sipil pada tahun 1974. Dengan jejaring yang cukup luas di Jakarta, Burhan dengan kelompok musik binaannya berhasil menyajikan musik Arumba di TVRI pada tahun 1980. Selanjutnya, atas ide dari pihak TVRI mereka melakukan kolaborasi dengan deretan artis terkenal waktu itu seperti Hetty Koes Endang dan Benyamin Sueb.

Pada titik ini, dapat dilihat bagaimana perjalanan karir Burhan sangat dipengaruhi oleh beberapa faktor, antara lain sifat inovatif dengan selalu ingin berkreasi, senang pada suatu hal yang baru, terutama faktor kebutuhan dan ekonomi. Seperti yang diungkapkan oleh Dyson (dalam Dewi, 2017: 146) bahwa hal tersebut dapat dikategorikan sebagai sikap menerima (responsif terhadap situasi yang ada).

Fenomena seperti ini sebenarnya terjadi juga pada salah satu jenis musik bambu, yaitu karinding. Popularitas karinding dapat diasumsikan sebagai hasil dari upaya para pelakunya dalam memelihara ke- berlangsungan kelompoknya, dengan cara memanfaatkan media sosial atau media elektronik seperti radio dan televisi (Daryana, 2017: 357). Pola yang sama dapat ditemukan dalam kasus ini. Oleh karenanya, dapat kita asumsikan bahwa sampai saat ini pola ini merupakan pola yang sangat efektif dalam menjaga sekaligus memopulerkan sebuah seni pertunjukan.

\section{Musik Arumba di Institusi Pendidikan}

Salah satu kontribusi besar yang dapat dianggap sebagai puncak aktivitas kreatif Udjo, melalui SAU, adalah menjadi salah satu seniman yang mengantarkan angklung sebagai kesenian yang tercatat sebagai warisan budaya dunia tak benda oleh UNESCO pada tanggal 16 November 2010 (Musthofa, 2015). Berkat pengakuan itu, akhirnya pemerintah memandatkan dibukanya Program Studi Angklung dan Musik Bambu di tahun 2012 melalui surat keputusan Direktorat Jenderal Pendidikan Tinggi Departemen Pendidikan Nasional Republik Indonesia Nomor: 149/E/O/2012 tanggal 27 April 2012. Prodi Angklung dan Musik Bambu ISBI Bandung didirikan sebagai institusi pendidikan tinggi yang diharapkan akan menjadi pelopor pembaharuan serta rujukan dalam disiplin ilmu musik, khususnya Angklung dan Musik Bambu.

Momentum tersebut disambut dengan baik oleh sivitas akademik ISBI Bandung. Dalam perwujudannya, musik Arumba dijadikan salah satu mata kuliah unggulan yang ada di Prodi Angklung dan Musik Bambu. Sampai saat ini, pembenahan pembelajaran musik Arumba terus dilakukan dengan cara eksperimen dan penelitian. Sebagai sebuah seni pertunjukan yang berusia cukup tua, Arumba sebagai sebuah ensambel menjadi sebuah mata kuliah unggulan. Pada awal dibentuknya Prodi Angklung dan Musik Bambu, musik Arumba diajarkan selama 4 semester dari semester 1 sampai dengan semester 4 . 
Seiring banyaknya revisi dan perbaikan kurikulum setiap tahunnya, maka sampai sekarang (2017) musik Arumba hanya diajarkan selama 3 semester. Selain itu, musik Arumba menjadi sebuah format ensambel favorit yang menjadi pilihan mahasiwa dalam menyelesaikan tugas akhir. Walaupun harus ditambahkan dengan instrumen lain, seperti angklung toel, synthetiser, dan instrumen musik lainnya yang disesuaikan dengan kebutuhan mahasiswa.

Lebih jauh lagi, Carumba (Calung Arumba), atau lebih dikenal sebagai gambang bambu, sebagai salah satu instrumen yang menghiasi ensambel Arumba diposisikan sebagai tolok ukur keterampilan (di samping Angklung Toel dan Angklung Gantung) mahasiswa Prodi Angklung dan Musik bambu yang akan menyelesaikan Ujian Resital Tugas akhir.

Mengingat pentingnya kedudukan mata kuliah musik Arumba di Prodi ini, maka eksperimen, penelitian, dan pengembangan terkait jenis musik ini dianjurkan oleh pihak Jurusan Musik yang menaungi Prodi Angklung dan Musik Bambu untuk terus dilakukan. Sederet rencana penelitian dan pengembangan (musik, instrumen, dan metode pembelajaran) masih dalam proses penggodokan untuk dirumuskan ke dalam kurikulum yang mencakup format musik, instrumen, dan metode pelatihannya.

Pembelajaran yang dilakukan selama 5 tahun memengaruhi orientasi musik Arumba yang berbeda dengan pendahulunya. Respon anak-anak muda sekarang lebih mengarah pada kelompok musik Arumba yang mempunyai visi dan semangat yang cukup segar. Kesadaran lokalitas mereka rajut dengan gaya dan pemahaman mereka sendiri. Dengan masuknya instru-

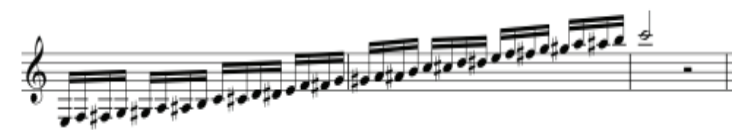

Gambar 3. Wilayah nada angklung gantung dalam ensambel Arumba (Sumber: Transkripsi Daryana, 2017) men musik barat dari mulai bass elektrik, gitar elektrik, drum set, violin, bahkan synthetiser, menjadikan budaya lokal bersifat dinamis dan terbuka, sehingga terlihat kreativitas kultural baru yang muncul ke permukaan sesuai perkembangan zaman.

\section{Karakteristik Musik Arumba}

\section{Formasi Musik Arumba dan Fungsi Instrumen}

Komposisi alat yang diaransemen oleh Burhan sebagai pembaharu musik Arumba, meliputi:

\section{a. Angklung Melodi}

Wilayah suara mencakup e kecil sampai dengan $c^{\prime \prime \prime}$ sebanyak 33 buah Angklung. Angklung melodi ini digantungkan pada sebuah tiang gantungan dengan posisi sejajar antara nada pokok dengan sisipannya. Fungsi angklung gantung dalam ensambel Arumba adalah sebagai melodi pokok (tema) atau pembawa lagu.

b. Calung Arumba (Carumba)

Instrumen berikut ini dinamakan calung karena memang bentuknya menyerupai calung renteng dari Cipatujah yaitu, sebuah alat musik bambu tradisional Jawa Barat yang berupa tabung-tabung bambu bernada pentatonis yang disusun sejajar dari nada rendah ke nada tinggi sebanyak beberapa oktaf. Dikarenakan Calung Arumba bernada diatonis maka, dinamakan Carumba atau kependekan dari Calung Arumba.

Jumlah Carumba dalam sebuah ensambel Arumba biasanya berjumlah 4 set dalam

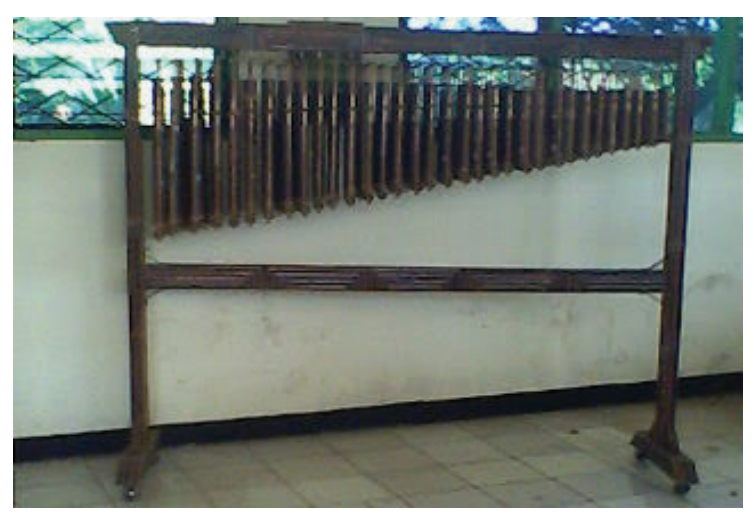

Gambar 4. Angklung melodi (Dokumentasi: Burhan, 2009) 


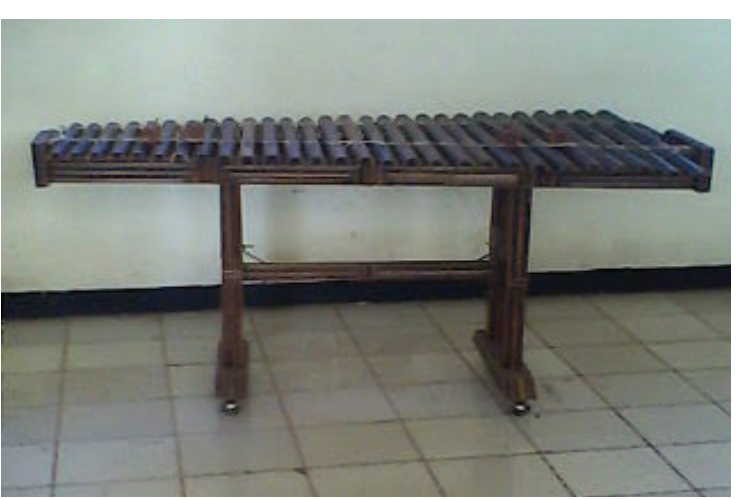

Gambar 5. Carumba

(Dokumentasi: Burhan, 2009)

berbagai oktaf, dengan maksud 2 set untuk memainkan variasi atau isian (fill) dan 2 set lagi menjadi pengiring (rhythm), atau bisa juga sebagai pembawa lagu bergantian dengan angklung melodi. Arumba melodi (variasi/improvisasi) juga terdiri dari 2 set, susunan nadanya terdiri dari: e oktaf kecil sampai dengan a" sebanyak 30 tabung untuk Carumba melodi 1 dan B oktaf besar sampai dengan fis" sebanyak 32 tabung untuk Arumba melodi.

c. Bas lodong

Bas lodong merupakan instrumen dalam ensambel Arumba yang terbuat dari bambu berukuran besar dan berfungsi layaknya instrumen bass pada combo band, yaitu beat keeper (penjaga irama) dan pengisi nada rendah. Instrumen ini disusun dalam satu oktaf dari mulai nada fis sampai dengan nada $G$ kecil (14 tabung).

Perpaduan instrumen ini merupakan perangkat pokok yang dapat juga ditambah dengan alat-alat perkusi lainnya, seperti kendang yang disimpan berdiri dan conga.

\section{Teknik Memainkan Alat-alat Musik Arumba}

Dari modul yang pernah disusun oleh Burhan sejak dia bekerja di Dinas Pariwisata DKI Jakarta dipaparkan bahwa pada dasarnya terdapat perlakuan sedikit berbeda dalam memainkan alat-alat musik Arumba. Hal itu dikarenakan seluruh alatalat musik Arumba tersebut terbuat dari bahan bambu. Secara prinsip teknik-teknik

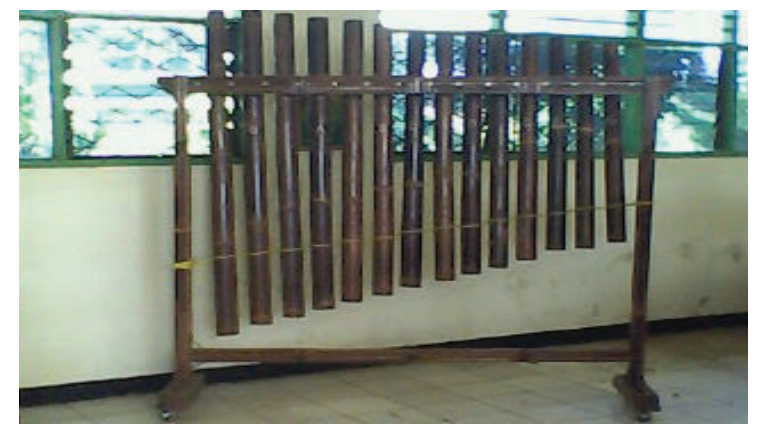

Gambar 6. Bass Lodong

(Dokumentasi: Burhan, 2009)

ini meliputi beberapa teknik yang secara khusus dimainkan dalam alat-alat musik yang ada dalam ensambel Arumba, yaitu:

\section{Angklung Melodi}

Angklung melodi adalah angklung yang berfungsi membawakan melodi utama. Cara menggetarkan Angklung Gantung ini ialah menggetarkan angklung tersebut ke arah depan dan belakang secara cepat dengan tangan kanan atau tangan kiri. Untuk mendapatkan getaran yang baik, peganglah bagian bawah dari tiang angklung (dekat dasar angklung) dengan satu atau dua jari (telunjuk, jari tengah, dan jari manis) di bagian dalam, sedangkan ibu jari di bagian luar.

Dalam memainkan nada yang tertuang dalam notasi secara rapih, maka dianjurkan dimainkan oleh tangan kanan dan kiri secara bergantian. Sebagai tambahan, agar suara angklung yang dihasilkan tidak terputus-putus, maka sebelum not yang kedua atau berikutnya dibunyikan, bunyi not yang pertama atau sebelumnya jangan diberhentikan terlebih dahulu, sebelum not selanjutnya dibunyikan.

\section{Carumba}

Terdapat dua jenis pukulan dalam memainkan Calung Arumba (Carumba), antara lain:

a. Pukulan staccato yaitu pukulan yang dimaksudkan untuk memainkan not-not yang bernilai pendek.

b. Pukulan jenis getaran (roll) untuk memainkan not-not yang bernilai panjang. Teknik pukulan ini jenis ini dimainkan secara bergantian antara tangan kanan dan 


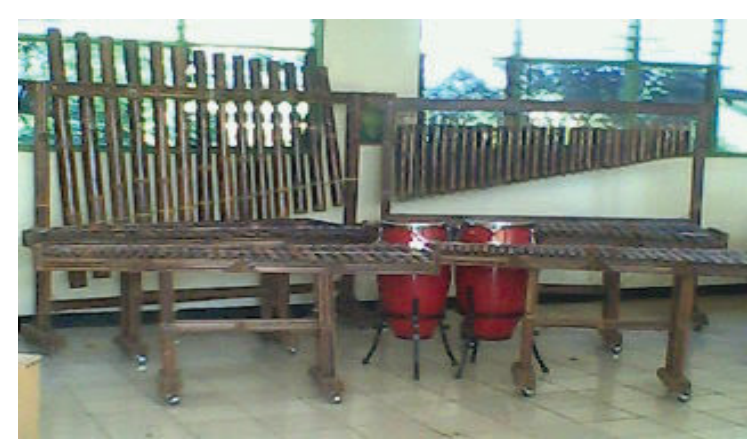

Gambar 7. Satu Unit Arumba

(Dokumentasi: Burhan, 2009)

tangan kiri atau sebaliknya pada not yang ditentukan, secara cepat dan rata.

3. Bass Lodong

Bass lodong dimainkan dengan cara menggunakan stick (panakol) yang dipukulkan persis di tengah ruas bass lodong itu.

\section{Bentuk Pertunjukan Musik Arumba}

Sebagai salah satu bentuk musik dalam format ensambel, dalam setiap pertunjukannya selalu dimainkan beberapa lagu-lagu yang sedang populer di tengah masyarakat. Lagu-lagu yang dibawakan biasanya instrumental atau diiringi vokal, bisa klasik, latin, pop, tango, waltz, bahkan jazz. Pada dasarnya, bentuk pertunjukan musik Arumba bersifat fleksibel, dipengaruhi oleh grup atau kelompok musiknya. Namun demikian, secara umum bentuk pertunjukan musik Arumba dapat dikategorikan ke dalam beberapa komponen, berikut ini:

1. Formasi Penyajian Ensambel Musik Arumba

Formasi yang dimaksud adalah penataan elemen-elemen penyajian dalam sebuah pertunjukan, yang meliputi: penempatan instrumen yang digunakan dalam sajian musik Arumba, tempat pertunjukan, jumlah pemain, waktu pertunjukan, dan repertoar (susunan lagu). Dapat disimpulkan dalam skema formasi penyajian ensambel Musik Arumba seperti dapat dilihat pada gambar 8 .

Skema tersebut bersifat tentatif atau dapat berubah-ubah sesuai band atau grup yang menyajikannya. Selain itu, beberapa

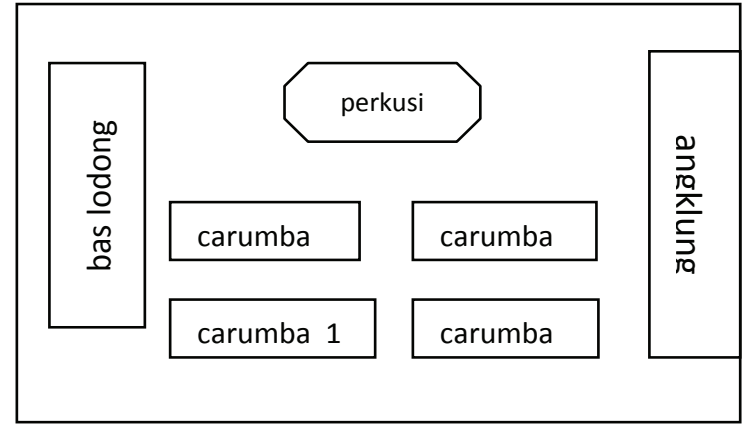

Gambar 8 Skema Penataan alat Musik Arumba (Sumber: Daryana, 2017)

faktor seperti tempat pertunjukan, ukuran panggung, dan jenis panggung sangat mempengaruhi tata letak instrumen dalam sebuah penyajian musik Arumba.

2. Tempat Pertunjukan

Kegiatan atau event yang diselenggarakan menjadi penentu lokasi pertunjukan Musik Arumba. Sebagai seni pertunjukan yang berfungsi hiburan musik Arumba dapat dipentaskan di dalam atau di luar ruangan. Seringkali musik Arumba dipentaskan di dalam gedung pertunjukan, pendopo, hotel, lapangan, atau bahkan di rumah orang yang membutuhkan jasa hiburan dalam acara pernikahan.

\section{Jumlah Pemain}

Jumlah pemain dalam sebuah ensambel musik Arumba juga beragam, jika berkaca pada format ensambel musik Arumba pada awal kelahirannya, maka hanya dibutuhkan 7-9 orang pemain. Masing-masing pemain memainkan satu buah instrumen ditambah vokal, perkusi, dan suling sebagai pelengkap. Berbeda dengan format ensambel musik Arumba versi Muhamad Burhan, perkembangan terkini masyarakat lebih cenderung memilih instrumen yang lebih praktis, dan ditambahkan penggunaan instrumen drum. Drum menjadi instrumen wajib yang harus disertakan dalam penyajian musik Arumba sekarang ini. Penambahan alat musik lainnya yang sering ditemukan adalah angklung toel, angklung takol gitar, bass elektrik, suling (bangsing atau flute), dan synthetiser. 


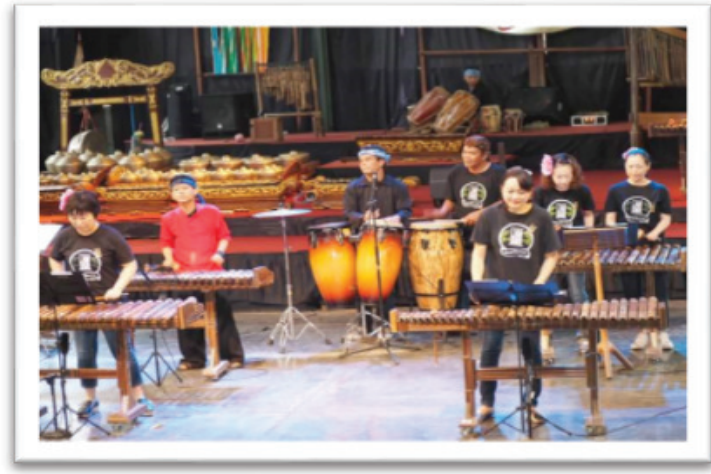

Gambar 9. Penyajian Grup Arumba Buluh Perindu di Saung Angklung Udjo (Dokumentasi: Budi Abdulrahman, 2017)

Dengan kata lain, masyarakat, atau lebih tepatnya anak muda, lebih berorientasi pada perpaduan musik yang lebih modern dengan tujuan ingin lebih merangkul anak muda lainnya agar menyukai dan memberikan perhatian lebih bagi musik Arumba. Dari perkembangan tersebut, dapat dilihat bahwa jumlah personil (pemain) tentunya sangat ditentukan dari konsep musik yang diusung oleh grup musik Arumba yang dimaksud.

Beberapa grup musik mahasiswa prodi Angklung dan Musik Bambu ISBI Bandung mempunyai konsep dan konfigurasi alat yang cukup beragam dalam penyajian musiknya. Hal itu pun berpengaruh pada jumlah pemain dalam grup mereka. Berdasarkan data di lapangan, peneliti menemukan bahwa beberapa grup musik Arumba masa kini memiliki personil antara 10-13 pemain. Tabel 1 menjelaskan konfigurasi alat dan jumlah pemain dari beberapa grup yang dapat dikategorikan sebagai musik Arumba masa kini dari ISBI Bandung.

4. Waktu Pertunjukan, Durasi Pertunjukan, dan Repertoar

Waktu pertunjukan musik Arumba biasanya mengikuti susunan acara yang telah disusun oleh penyelenggara acara, bisa pagi, siang, sore, atau malam. Waktu itu pun akan berubah ketika musik Arumba dipentaskan dalam acara yang berbeda seperti festival musik, acara kantor seperti peluncuran produk baru, atau bahkan

\begin{tabular}{lll}
\hline Swarantara & Bambu 212 & Paberik Bambu \\
\hline $\begin{array}{l}\text { carumba } \\
\text { melodi } 1\end{array}$ & $\begin{array}{l}\text { carumba } \\
\text { melodi } 1\end{array}$ & carumba melodi 1 \\
& $\begin{array}{l}\text { carumba } \\
\text { melodi } 2\end{array}$ & carumba melodi 2 \\
carumba & $\begin{array}{l}\text { carumba } \\
\text { melodi 3 }\end{array}$ & carumba melodi 3 \\
angklung & angklung & angklung takol 1 \\
gantung & gantung & \\
angklung & gitar & angklung takol 2 \\
toel & elektrik & \\
bass & bass elektrik & gitar elekrik \\
elektrik & & \\
gitar & drum & bass elektrik \\
elektrik & & \\
drum & saxophone & synthetiser \\
& kendang & kendang sunda \\
& sunda & drum \\
\hline
\end{tabular}

\section{Tabel 1.}

Konfigurasi alat dan jumlah pemain grup musik Arumba dari ISBI Bandung (Daryana, 2019)

dalam acara wisuda yang diselenggarakan oleh sebuah perguruan tinggi.

Idealnya sebuah pertunjukan musik Arumba berkisar antara 30-45 menit, sehingga dari rentang waktu yang biasa diberikan oleh penyelenggara acara itu, sebuah grup Arumba biasanya membawakan sekitar 6-7 lagu.

5. Media Tampilan

Tampilan lain yang seringkali menjadi penunjang dalam sebuah pertunjukan musik Arumba ialah kostum. Memang tidak terdapat kostum khusus dalam pertunjukan Arumba, akan tetapi masing-masing grup musik Arumba mempunyai gaya masing-masing untuk menunjang penampilan di atas panggung. Identitas musik Arumba, yang seringkali didentikkan dengan musik Sunda, menjadi satu dorongan dalam pemilihan kostum. Tidak jarang banyak grup musik Arumba yang menggunakan kostum dengan gaya tradisional atau bahkan beberapa grup musik Arumba masa kini cukup menggunakan kaos atau kemeja untuk mendukung citra grupnya. 


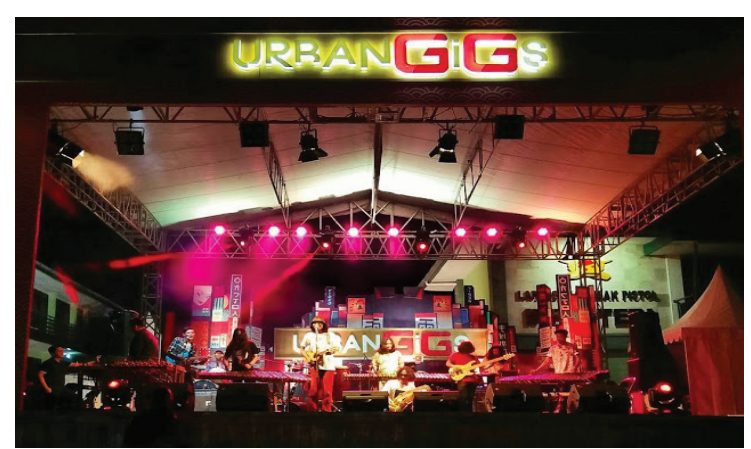

Gambar 10. Gaya Kostum kasual Paberik Bambu (Dokumentasi: Bamboe, 2017)

\section{Sketsa Transformasi Musik Jorgensen}

Berikut ini adalah 5 sketsa musik yang menggambarkan banyak hal ketika musisi dan pendidik musik memahami dan mempraktikkan musik. Selain itu, Jorgensen (2005) juga menjelaskan secara garis besar 3 (tiga) cara bagaimana musik itu ditransformasikan:

1. Musik sebagai Objek Estetik

Memahami musik, dalam pandangan ini, mengharuskan kita untuk menangkap asumsi mendasar yang menentukan apa yang didengar dan dilihat di dunia fenomenal dan struktur formalnya untuk melihat bagaimana hal itu dibuat.

2. Musik sebagai Simbol

Terkait dengan gagasan musik sebagai objek estetika adalah pandangan lain yang mencapai keunggulan di bagian akhir abad ke-20, dan menandakan bagaimana musik dirasakan dan memiliki makna bagi penciptanya dan publik. Para peneliti yang menggunakan pandangan ini dalam meneliti musik termasuk psikolog musik yang mempelajari bagaimana orang mendengar, mempersepsikan, memikirkan atau belajar mengembangkan kemampuan dan keterampilan khusus, dan membuat musik. Mengartikulasikan sifat simbol musik juga mengharuskan kita mengakui pentingnya imajinasi dan intuisi sebagai alat untuk memahami sistem simbol yang inheren dan ambigu.

3. Musik sebagai Kegiatan Praktis

Musisi harus memiliki pengetahuan prosedural untuk terus membuat musik, karena keterampilan teknis dan kritis yang didapat oleh para ahli digunakan terutama untuk membuat musik daripada membuat sebuah teori tentangnya. Sementara dalam mempraktikkannya, seorang pemusik selalu berpikir tentang musik secara abstrak dan teoretis. Fokus utama mereka adalah pada apa dan bagaimana sebuah lagu itu dinyanyikan dan sebuah instrumen harus dimainkan.

4. Musik sebagai Pengalaman

Alih-alih berfokus pada perolehan keterampilan teknis dan kritis seperti yang terlihat pada pandangan musik sebagai praktik, citra ini memungkinkan orang untuk menghubungkan sifat pengalaman musik tertentu mereka melalui sarana, seperti jurnal, percakapan, dan artefak musikal (misalnya pertunjukan solo dan ensambel dalam setting tradisional, rekaman, situs web, dan pertunjukan yang dihasilkan secara elektronik.

\section{Musik sebagai Agensi}

Citra musik sebagai agensi merujuk pada nilai musik sebagai sarana untuk mencapai politik, sosial, agama, psikologis, pendidikan, atau ekonomi, dan kebajikan moral menindas atau membebaskan orang, mengubah tradisi musik dan pendidikan dan masyarakat luas, dan meramalkan masyarakat masa depan. Dalam hal ini, nilai musikal muncul karena pentingnya tujuan lain daripada kelebihan intrinsiknya sebagai wujud musik untuk musik. Tidak seperti musik sebagai narasi, musik sebagai agensi ini merupakan sarana untuk mencapai tujuan lain. Sebagai kekuatan sosial, politik, agama, ekonomi, dan psikologis, musik mencerminkan nilai kelembagaan dan pribadi, serta membantu membentuk institusi tempat musik ini menjadi bagian, dan individu yang membentuk masyarakatnya.

Sementara itu, dalam mentransmisikan sketsa tersebut Jorgensen (2005) menawar- 
kan tiga mekanisme dalam transformasi musikal. Pertama, pada konteks budaya ketika musik itu dibuat dan menjadi terkemuka sehingga berdampak pada musik musik itu sendiri; kedua, didasarkan pada sifat musik, terutama sifat simbolis musik dan interpretasinya, sifat musikal, dan karakter selera musik; dan ketiga berkaitan dengan proses transmisi musikal, terutama caracara tempat keyakinan dan praktik musikal berpindah dari satu generasi ke generasi berikutnya.

\section{Proses Terjadinya Transformasi Musik Arumba}

Ditinjau dari aspek historis-kultural, musik Arumba berakar dari tiga tradisi musikal, yakni musik Sunda, Barat, dan Latin. Artinya, Daeng Sutigna sebagai penggagas Angklung diatonis, yang kemudian dikembangkan oleh Burhan, memiliki kesadaran dialektis untuk melakukan apropriasi terhadap budaya asing yang dianggap bisa dominan dalam masyarakat. Hal itu sebagai akibat berkembangnya industri budaya pop di Indonesia pada waktu itu.

Momentum inilah yang meyakinkan Burhan untuk membuat sebuah terobosan. Setelah memahami struktur dasar angklung, baik secara organologis maupun musikal, Burhan kemudian memutuskan untuk melakukan penggabungan budaya dalam melahirkan Musik Arumba.

Hibriditas bisa jadi merupakan telaah yang relevan dalam melihat perpaduan tersebut. Lahirnya seni tradisi di dalam lingkungan urban yang mengglobal berlangsung sebuah proses kultural yang kompleks dan melibatkan sebuah proses silang budaya. Hassan (dalam Piliang, 2011: 242) memandang bahwa hibridisasi adalah proses penciptaan atau replikasi bentukbentuk mutan melalui perkawinan silang, yang menghasilkan entitas campuran yang tidak lagi utuh, meskipun di dalamnya masih tersisa sebagian identitas diri dari dua unsur yang dikawinsilangkan.
Instrumen musik bambu, yang termasuk dalam ensambel Arumba, yang berkembang pasca-1970 tentu saja tidak tiba-tiba hadir dalam ruang kebudayaan masyarakat. Semua instrumen musik Arumba tersebut diciptakan dari hasil dialog dengan beberapa kultur yang mendominasi saat itu. Konsepsi hibriditas musikal tersebut juga dapat diidentifikasi sejak berlangsungnya modifikasi yang dilakukan Daeng Sutigna dengan angklung diatonis (sebagai influence diciptakannya Arumba). Didorong oleh rasa prihatin terhadap kondisi mayoritas anak didiknya yang kurang berminat untuk belajar musik dan seni vokal, akhirnya dengan modal keterampilan penguasaan alat musik barat seperti gitar, piano, mandolin, dan biola serta dibantu oleh seorang pengrajin bernama Djaja, Daeng berhasil melakukan perpaduan instrumen angklung (lokal) yang bernada diatonis (global), dengan tujuan untuk dijadikan sarana pendidikan kesenian dan untuk mengiringi lagu-lagu barat yang kala itu tengah populer (Rosyadi, 2017).

Hal yang menarik untuk dicermati adalah bagaimana pertunjukan musik Arumba secara implisit merekam aspek-aspek perubahan sosial dalam masyarakat sebagai akibat mulai semaraknya modernitas dalam kehidupan sehari-hari mereka. Repertoar lagu-lagu yang dibawakan pada masa itu menandakan bahwa mereka hidup dalam dunia yang tengah berubah, namun tetap berusaha melakukan negosiasi dan transformasi nilai-nilai tradisional dalam kehidupan urban. Padahal sebagai seorang seniman, sosok-sosok pionir musik bambu ini (Angklung Pak Daeng dan Arumba) tidak mampu untuk membendung pengaruh diskursif dan estetik yang ditimbulkan oleh modernitas. Hal menarik lainnya dan sangat layak direnungkan lebih jauh adalah pilihan ideologis yang diambil oleh kedua sosok ini. Artinya, mereka mampu memandang, mengamati, dan memahami segala 
bentuk perubahan zaman yang terjadi, dan dengan itu mereka melakukan perpaduan menarik antara wacana lokal dan global.

Kemampuan memadukan tiga kultur yang berbeda yang jelas-jelas berbeda secara tatanan maupun makna filosofinya tersebut merupakan usaha kultural untuk memformulasi sebuah musik hibrid dengan tidak meninggalkan kesundaan, yang direpresentasikan melalui angklung, carumba, dan bass lodong, di tengah-tengah modernitas yang direpresentasikan oleh nada yang digunakan (diatonis) dan conga.

Dalam upaya mengkaji transformasi musik Arumba, peneliti mencermati bahwa setidaknya terdapat beberapa perubahan yang ikut andil dalam mendorong transformasi musik Arumba. Perubahan yang terjadi pada aspek-aspek dalam musik Arumba sesuai dengan apa yang diungkap Jorgensen (2005) dalam teori sketsa musik.

Berawal dari musik sebagai objek estetik, Burhan sepenuhnya sadar bahwa musik merupakan bagian dari hidupnya. Sejak dikenalkan oleh orangtuanya, Burhan kemudian terdorong melakukan aktivitas yang berhubungan dengan musik. Sejak remaja sampai hari ini, aktivitas yang dilakukan pasti terkait dengan pertunjukan, pelatihan, dan pengajaran musik.

Terkait dengan transformasi musik Arumba, sebelum melakukan perubahan, Burhan terlebih dahulu melakukan observasi dan eksperimen. Observasi dilakukan pada saat mengapresiasi pertunjukan Joes Rosadi dan perkembangan musik populer secara umum. Kemudian, dengan pengetahuan yang ia punya, Burhan melakukan beberapa inovasi dengan membuat instrumen yang melengkapi ensambel Arumba saat ini.

Ketika cikal bakal musik Arumba perlahan terwujud, Burhan kemudian ingin memosisikan musik Arumba sebagai simbol dari musik Sunda. Bahan dasar bambu dan dominannya instrumen akustik (tanpa elek- trifikasi) yang dipilih untuk merepresentasi musik Sunda, umumnya, Indonesia.

Dengan berbagai upayanya Burhan kemudian secara rinci melakukan eksperimen secara musikal. Hasilnya, Burhan berhasil membuat sebuah inovasi dari segi instrumen dan cara memainkannya. Carumba dan bass lodong adalah instrumen yang kemudian diidentikkan dengan musik Arumba.

Selama puluhan tahun Burhan bergelut dengan musik Arumba dan berhasil membawanya pada posisi yang cukup bergengsi. Beragam produk sudah dihasilkan baik itu album atau pun video turorial cara memainkan Arumba. Dikaitkan dengan apa yang dikemukan Jorgensen (2005), album dan video tutorial tersebut dapat dipahami sebagai sebuah media untuk menghubungkan sifat dan pengalaman bermusik Burhan.

Pada konteks ini, Muhamad Burhan sebagai pembaharu Arumba mempertahankan kandungan nilai-nilai budaya Sunda tersebut kemudian dikembangkan berdasarkan daya imajinasi dan kreativitas sesuai zaman. Berbekal modal budaya yang digagas oleh Bourdieu (1977), yaitu keseluruhan kualifikasi intelektual yang bisa diproduksi melalui pendidikan formal maupun warisan keluarga, Burhan mampu memadukan dua, bahkan tiga kebudayaan dalam musik yang dia kembangkan.

Sejalan dengan arah pemikiran Burhan, Jorgensen (2005) memberi pandangan bahwa transformasi dapat dimaknai sebagai perubahan mindset yang terjadi karena keinginan untuk tetap mempertahankan eksistensinya. Daya kreasi Burhan seketika itu muncul saat melihat angklung Pak Daeng, perubahan mindset bahwa seni tradisional harus selalu mengikuti pakem yang sudah ada, senantiasa didobrak oleh Burhan. Dia memberanikan diri untuk melakukan sebuah trannsformasi bentuk dan struktur angklung waktu itu untuk mencapai tujuan mulia yaitu menjaga kelangsungan seni tra- 
disional, lebih luas lagi kebudayaan Sunda. Tidak dipungkiri juga musik Arumba juga menjadi kendaraan bagi meningkatnya status sosial Burhan.

\section{SIMPULAN}

Dapat disimpulkan bahwa setidaknya telah terjadi 2 (dua) bentuk transformasi, yaitu musik yang meliputi beberapa tahapan yang dijelaskan dalam diagram berikut ini:

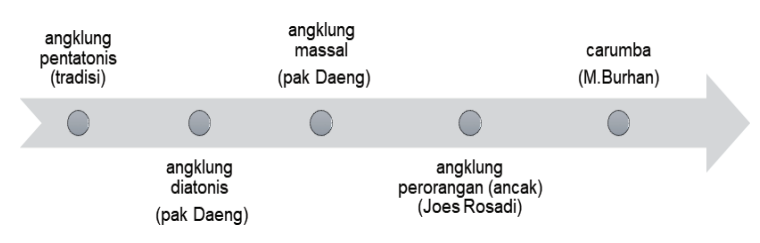

Juga perubahan fungsi yang masingmasing di antaranya mempunyai keunikan dan proses yang berbeda. Secara singkat, perkembangan itu dapat dilihat dari diagram, berikut ini:

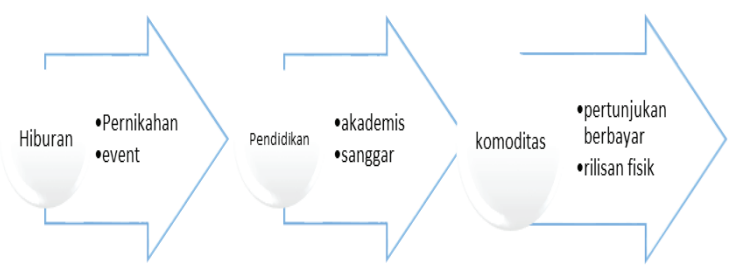

Pertunjukan musik Arumba merekam aspek-aspek perubahan sosial dalam masyarakat akibat modernitas. Repertoar lagu-lagu yang dibawakan juga menandakan bahwa mereka hidup dalam dunia yang tengah berubah, namun tetap berusaha melakukan negosiasi dan transformasi nilai-nilai tradisional dalam kehidupan urban. Pilihan ideologis yang diambil oleh Daeng Soetigna dan Mochamad Burhan menjadi tanda bahwa mereka mampu memandang, mengamati, dan memahami segala bentuk perubahan zaman yang terjadi.

Masyarakat umum memandang musik Arumba sebagai representasi dari kultur Sunda. Padahal, pada kenyataannya ia merupakan bentuk seni hibrid yang di dalamnya terkait elemen kebudayaan lain, sebagai suatu fenomena yang terkonstruksi akibat dari globalisasi. Transformasi nilai yang terjadi bisa jadi merupakan usaha atau kegiatan yang dilakukan untuk tetap melestarikan atau mengembangkan nilai-nilai yang terkandung dalam budaya agar budaya tersebut dapat menjawab kompleksitas permasalahan yang dialami oleh masyarakat.

Dengan budaya hibrid masyarakat lokal akan kehilangan sebagian aspek kultural, tetapi di sisi lain entitas baru yang lahir ternyata mampu dikembangkan, disukai, bahkan dilestarikan oleh berbagai lapisan sosial. Berdasarkan simpulan di atas, penelitian ini jelas masih membutuhkan waktu untuk melakukan pendalaman. Untuk itulah, penelitian ini masih membutuhkan data lapangan kemudian di analisis secara mendalam untuk mencari keterkaitan dan pencarian model transformasi yang dapat dijadikan model pengembangan seni tradisi lokal.

\section{Daftar Pustaka}

Bamboe, P. (2017). Gallery. Retrieved November 20, $2017 \mathrm{http} / /$ www.paberik bamboe.com/p/gallery.html

Bourdieu, P. (1977). Outline of a Theory of Practice. Cambridge: Cambridge University Press.

Burhan, M. (2009). Riwayat Musik Angklung Arumba. Retrieved November 18, vember 18, $2017 \mathrm{http}: / /$ mohamadburhan.blogspot.com/2009/10/riwayatmusik-angklung-arumba.html

Daryana, H. A. (2017). The Popularity of Karinding among Bandung Society. Panggung, 27 (4), 353-362. doi: dx. doi.org/10.26742/panggung.v27i4. 291.g278

Denzin, N. K., \& Lincoln, Y. S. (1998). Collecting and Interpreting Qualitative $M a-$ terials. Thousand Oaks, Calif.: Sage Publications. 
Dewi, H. (2017). Keberlanjutan dan Perubahan Seni Pertunjukan Kuda Kepang di Sei Bamban, Serdang Bedagai, Sumatera Utara. Panggung, 26 (2), 139-150.

Jorgensen, E. R. (2005). Transforming Music Education. Bloomington Indiana University Press.

Musthofa, B. M. (2015). Strategi Keberhasilan Proses Pemberdayaan Masyarakat melalui Pengembangan Kreativitas Seni Tradisi: Studi Kasus Saung Angklung Udjo, Bandung, Jawa Barat. Sosio Konsepsia, 5 (1), 325-339.

Piliang, Y. A. (2011). Dunia yang Dilipat: Tamasya Melampaui Batas-batas Kebudayaan. Bandung: Matahari.
Rosyadi. (2017). Angklung: Dari Angklung Tradisional Ke Angklung Modern. Jurnal Penelitian Sejarah dan Budaya, Patanjala: 4 (1), 26-40. doi:dx.doi. org/10.30959/ptj.v4i1.122.

Sakrie, D. (2015). 100 Tahun Musik Indonesia. Jakarta: Gagas Media.

Saleh, Y. A. (2016). Dubes RI: Tahun Ini Pertama Kali Indonesia Jadi Tujuan Terfavorit Warga Australia. Retrieved from https://news.detik.com/berita/ /d-3303713/dubes-ri-tahun-ini-pertama-kali-indonesia-jadi-tujuan-terfavorit-warga-australia 